\title{
The Impact of Precipitation on Drinking Water Resources in the Sagarmatha National Park (Mt. Everest Region), Nepal
}

\author{
Kirsten Ngaire Nicholson ${ }^{1}$, Klaus Neumann1, Subodh Sharma ${ }^{2}$ \\ ${ }^{1}$ Department of Environment, Geology and Natural Resources, Ball State University, Muncie, IN, USA \\ ${ }^{2}$ School of Science, Kathmandu University, Kathmandu, Nepal \\ Email: ${ }^{\star}$ knichols@bsu.edu
}

How to cite this paper: Nicholson, K.N., Neumann, K. and Sharma, S. (2019) The Impact of Precipitation on Drinking Water Resources in the Sagarmatha National Park (Mt. Everest Region), Nepal. Journal of Water Resource and Protection, 11, 1351-1368. https://doi.org/10.4236/jwarp.2019.1111078

Received: September 16, 2019 Accepted: November 11, 2019 Published: November 14, 2019

Copyright () 2019 by author(s) and Scientific Research Publishing Inc. This work is licensed under the Creative Commons Attribution International License (CC BY 4.0).

http://creativecommons.org/licenses/by/4.0/

\begin{abstract}
This study focuses on the link between precipitation, the bacteriological characteristics, and the physical parameters of drinking water sources from 2016 to 2018 in the Sagarmatha National Park (Mt. Everest region), Nepal. Surface water shows a positive correlation between bacteria content, altitude and corresponding temperature, whereas water from springs shows no correlation between bacteria content and altitude and corresponding temperature. Correlation between precipitation data and both $\mathrm{pH}$ and conductivity suggests a link between drinking water quality and precipitation whereby high precipitation rates result in increased contamination of both surface water and springs used for drinking water. This data also indicates that during periods of low precipitation, water handling is likely to contribute to water contamination. These results highlight vulnerability to climate change as melting glacial ice and changing precipitation patterns are key factors for safe drinking water.
\end{abstract}

\section{Keywords}

Himalaya Mountains, Drinking Water, Precipitation, Fecal Contamination, Climate Change

\section{Introduction}

Mount Everest (known also as Sagarmatha and Chomolungma), the highest mountain in the world, is located in the Sagarmatha National Park, Nepal $\left(27^{\circ} 56^{\prime} \mathrm{N}, 86^{\circ} 44^{\prime} \mathrm{E}\right)$, which extends from $2610 \mathrm{~m}$ to $8848 \mathrm{~m}$ elevation. Communities in the Sagarmatha National Park and associated Buffer Zone (from here on 
known as the combined SNPBZ, Figure 1), some of the highest-altitude villages in the world experience poor health outcomes due to contaminated drinking water. Diseases initiated by contaminated water are some of the most common causes of death in developing nations. According to the World Health Organization [1], unsafe drinking water and inadequate sanitation practices are responsible for more than $80 \%$ of diseases globally, and specifically, contaminated drinking water contributes to more than one billion cases of diarrhea each year; yet, over 800 million people lack basic drinking water service [2]. These problems are more prevalent in developing countries where unsafe drinking water contributes to a number of health issues [2].

Availability and access to clean drinking water in the SNPBZ is a complex challenge, involving environmental degradation, economics, climate change, and governance. The park was established in 1976 with an area of $1148 \mathrm{~km}^{2}$, declared as a World Natural Heritage Site in 1979, and added a protective buffer zone of $\sim 275 \mathrm{~km}^{2}$ in 2002. Community, regional, and national governance within the park is multifaceted. The spectacular scenery attracts trekkers who simultaneously

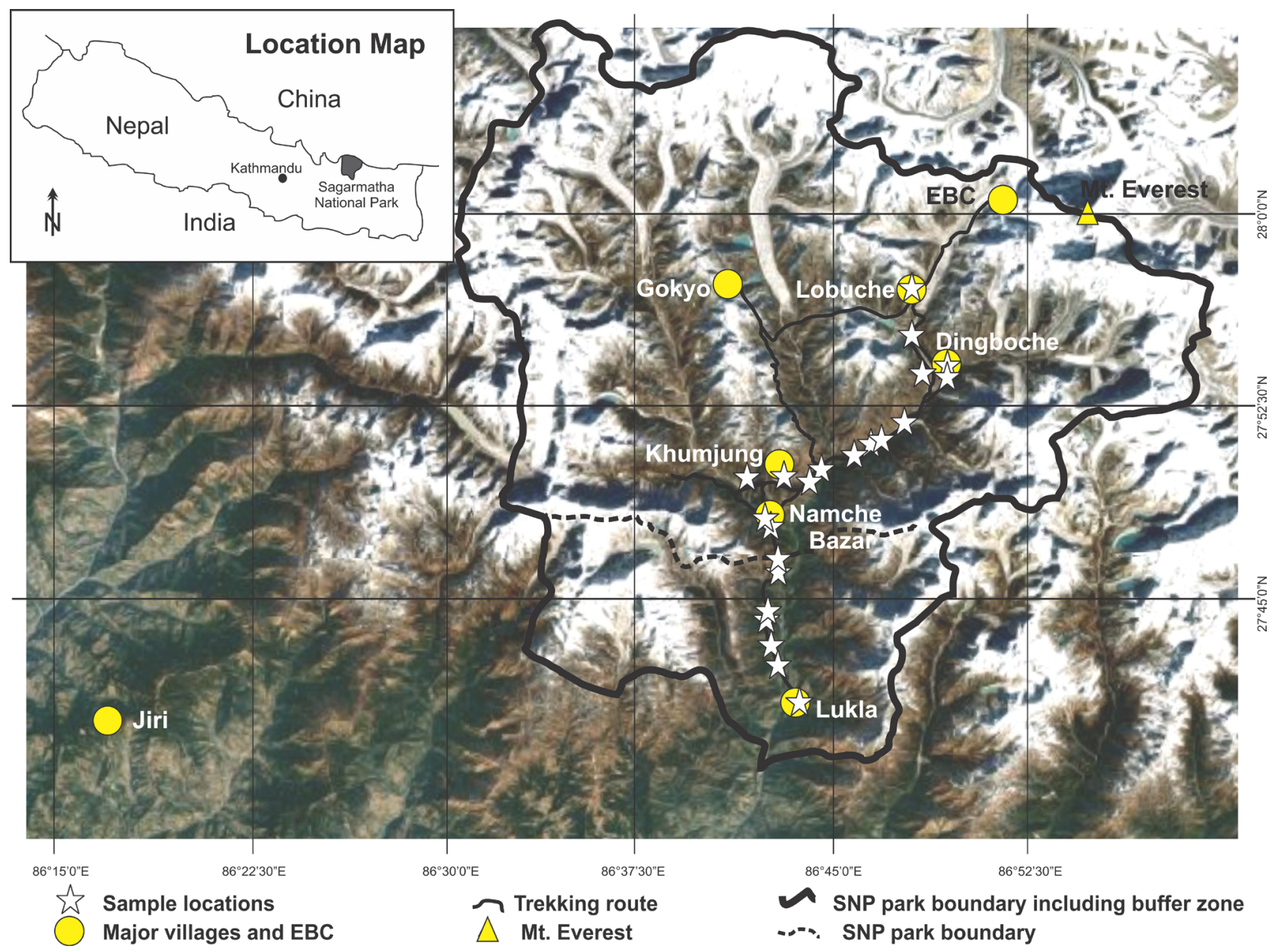

Figure 1. Location map showing the regional topography and drainage basins, with vegetation in green and snow/ice cover in white, for the SNP and surrounding area. The map also shows the location of Jiri where precipitation data is collected, major villages in the SNP and sampling locations. 
drive the local economy as well as contribute significantly to environmental degradation. The region has a local population of about 6000 people, while tourist numbers rose to peak numbers of 36,518 in 2012 , not even counting a large number of service personnel such as porters and guides who accompany the tourists [3] [4]. The refuse generated by tourists within the SNPBZ is causing substantial anthropogenic pressure with serious environmental consequences to the unique ecosystems [5] [6] [7]. Although the impact is visible primarily along the more popular trekking routes, unmanaged or poorly managed solid waste disposal and open defecation have resulted in contamination of major rivers [8] [6] [7] and many drinking water sources throughout the region [9] [10] [11].

In recent years, local communities have become more aware of and concerned about drinking water safety and water security [12] [13] [14] [15]. The onus of managing SNP's drinking water quality, and of managing sewage and waste, has devolved from the national government to citizens and communities across Nepal, including those of the SNPBZ. Healthy ecosystems and community welfare are interdependent and are at the heart of community-based ecosystem management [16]. Unfortunately, both the tourism industry's unchecked development and climate change are impacting ecosystem health, particularly drinking water quality, and people's quality of life; further compromising their ability to manage water resources in ways beneficial to the greater community. Hence, understanding a range of factors from household water use through localized hydrology is necessary in order to facilitate community-driven management and sustainability practices that support water quality risk mitigation and improve human health [17].

Water resources in the SNPBZ are not just important to local Sherpa communities. The Himalayan Mountains are the headwaters for major river systems such as the Ganges, Yangtze and Indus Rivers which provide water resources to approximately 1.4 billion people, hence understanding all aspects of the hydrologic cycle is important. The current and future impact of climate change, particularly glacial melting and changing precipitation patterns [18] and references therein], will affect all those dependent on Himalayan water resources. The threat to both water and food security in the region is significant, and understanding the impacts within the headwaters of the region must be fully explored in order that communities, regions and countries can act to reduce long-term vulnerability to climate change.

\section{Methods}

The study area begins in the SNPBZ township of Lukla, follows the main trekking route towards Mt. Everest base camp, and then drops back down to Lukla (Figure 1). Tourist and resident population numbers are highest at the lower elevations. The entire route is characterized by rugged terrain and topography, and ranges in altitude from $2610 \mathrm{~m}$ to $5300 \mathrm{~m}$. The SNPBZ has a temperate climate characterized by cold winters, warm summers and clear seasonality, with temperature ranges from $37^{\circ} \mathrm{C}$ in summer to $-17^{\circ} \mathrm{C}$ in winter. Maximum rainfall 
generally occurs between June and September, coinciding with the Indian Monsoon (Table 1).

Water samples were collected during the pre-monsoon season: late April and early May 2016, 2017 and 2018. Sampling sites are located along the main trekking route between Lukla and Lobuche (Figure 1) and were selected based on access to and availability of the water for local and tourist use as drinking water. Where possible, the actual source (generally springs) of drinking water was sampled. Sample sites include 16 samples of subsurface-fed springs (either directly from the spring or from flowing standpipes (water brought via tubing from springs at higher elevations), and 8 stream samples. Only water currently being used as drinking water was sampled, hence the major rivers are not included in this study. None of the samples were collected from standing or stored water.

Fecal contamination in water sources poses significant health risks; the presence of coliform bacteria and $E$. coli can be used as an indicator of fecal contamination of water and potential danger to human health. In natural systems, microorganisms are widely distributed and their diversity and abundances may be used as an indicator for suitable water sources [19]. Although there is a wide range of pathogenic microorganisms that can be transmitted to humans via water contaminated with fecal material (see [20] and references therein), the isolation and identification of these organisms are complicated and seldom quantitative [21] [22]. It is not practical to test water for all of these organisms, and measurement of coliform bacteria (total coliform bacteria and/or fecal coliforms) can be used as an indirect approach based on the assumption that groups of normal enteric organisms will indicate the level of fecal contamination of the water supply [22] [23] [24] [25] [26].

Temperature, $\mathrm{pH}$ and conductivity were measured in the field using a FisherSci Ap85 pH/conductivity meter. Samples for bacteria analyses were collected in sterile syringes and $100 \mathrm{~mL}$ of sample was passed through a $0.45 \mu \mathrm{m}$ filter at the sample site. After filtration the filter paper was placed in a sterile test card (manufactured by Micrology Labs ${ }^{\circledR}$ ) containing a medium which uses two color-producing chemicals, one for the detection of the enzyme glucuronidase (produced by $E$. coli strains but not by general coliforms) and one for the detection of galactosidase (produced by all coliforms, including E. coli). The samples were then placed into a portable field incubator and kept as close to $35^{\circ} \mathrm{C}$ as possible for 24 hours (for detailed field methods refer to [27]). Sample counts were done using a magnifying glass and a $10 \times$ geological hand lens. E. coli colonies are royal blue/purple and coliform bacteria colonies appear to be light green. Duplicate samples were run on every tenth sample and each sample was counted twice.

\section{Results}

Samples were taken from 24 different localities in April-May 2016, 2017 and 2018 (Figure 1). For the purpose of this study the samples will be discussed in terms of 
(a) overall trends $(\mathrm{n}=24)$, (b) surface water $(\mathrm{n}=8)$, and $(\mathrm{c})$ springs $(\mathrm{n}=16)$.

\subsection{Physical Parameters}

Physical parameters, plotted against altitude, are shown in Figure 2. The overall
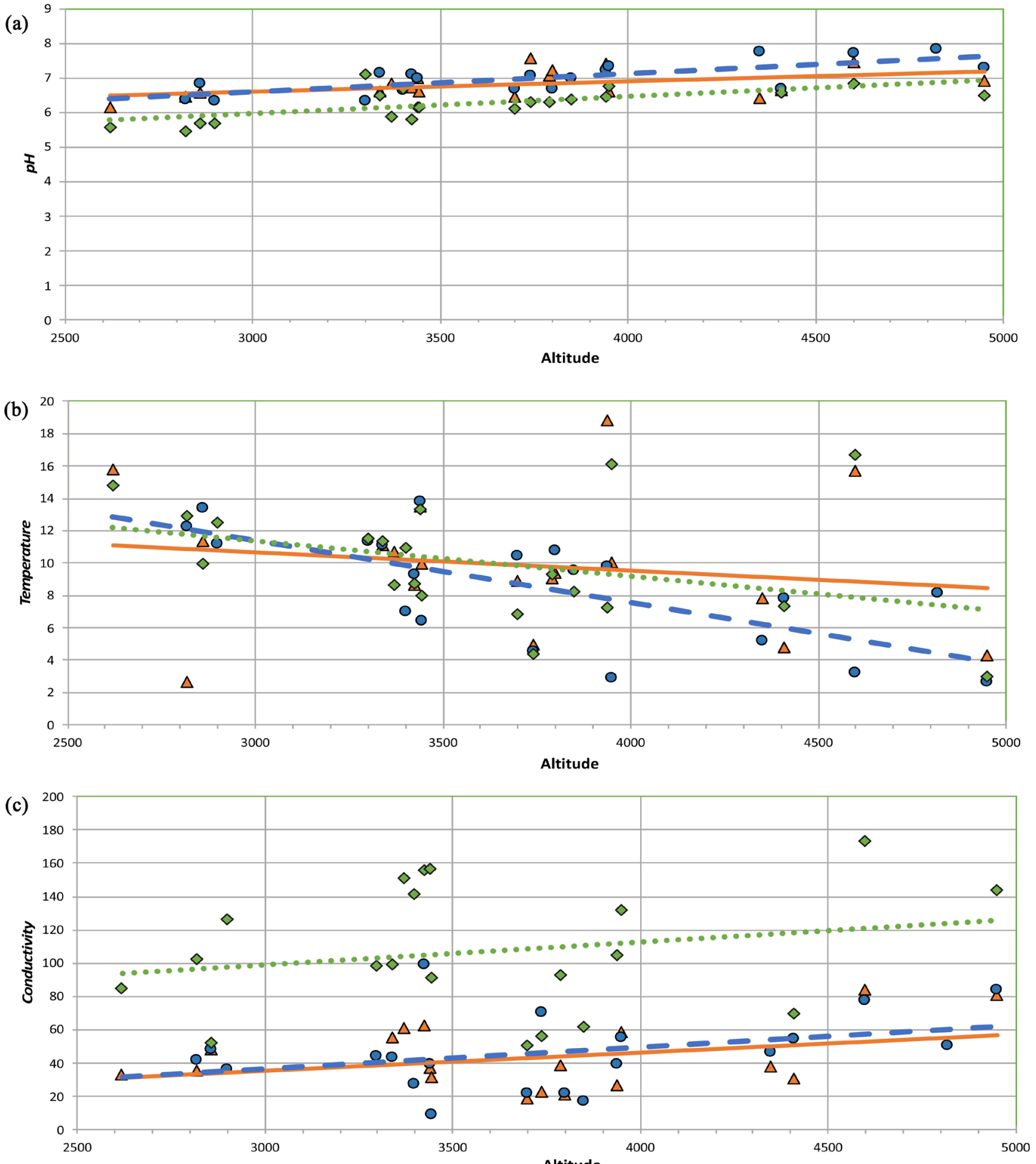

Figure 2. Physical parameters of (a) pH, (b) Temperature and (c) Conductivity plotted against altitude. 2016: filled diamonds and dotted line, 2017: filled circles and dashed line, 2018: filled triangles and solid line. 
trend for all samples is decreasing temperature and conductivity, and increasing $\mathrm{pH}$ with altitude. This same pattern is seen when the samples are separated in the surface water and springs (Figure 2). In 2016 average drinking water temperatures were $10.1( \pm 3.6)^{\circ} \mathrm{C}$ (surface water $9.7( \pm 5.0)^{\circ} \mathrm{C}$ and spring water 10.3 $\left.( \pm 2.9)^{\circ} \mathrm{C}\right)$. In all instances surface water is colder than spring water. In 2017 average drinking water temperatures were $8.5( \pm 3.5)^{\circ} \mathrm{C}$ (surface water 7.5 $( \pm 4.0)^{\circ} \mathrm{C}$, spring water $9.1( \pm 3.1)^{\circ} \mathrm{C}$ ), while in 2018 average drinking water temperatures were $9.8( \pm 4.3)^{\circ} \mathrm{C}$ (surface water $10.1( \pm 3.6)^{\circ} \mathrm{C}$, spring water 11.1 $\left.( \pm 3.3)^{\circ} \mathrm{C}\right)$. Water temperatures decrease with increasing altitude, with 2017 standing out with the steepest trend in temperature decrease.

In all years, $\mathrm{pH}$ shows a steady increase with altitude. 2016 had consistently lower $\mathrm{pH}$ levels than 2017 or 2018, with an average $\mathrm{pH}$ of all drinking water samples of $6.2( \pm 0.4)$ (vs $7.0( \pm 0.46)$ in 2017 and $6.8( \pm 0.4)$ in 2018). The average $\mathrm{pH}$ of surface water in 2016 was $6.3( \pm 0.5)$ (vs. $6.9( \pm 0.5)$ in 2017 and $6.8( \pm 0.4)$ in 2018) and the average for spring water was $6.2( \pm 0.4)$ (vs. $7.0( \pm 0.4)$ in 2017 and $6.7( \pm 0.4)$ in 2018).

The range in conductivity in the samples was relatively small with a maximum of $173.4 \mu \mathrm{S}$ in 2016 and a minimum of $8.6 \mu \mathrm{S}$ in 2017 . As with $\mathrm{pH}$, conductivity shows a weak positive correlation with altitude. 2016 had consistently higher conductivity levels than 2017 or 2018, with an average for all drinking water samples of $107.0( \pm 38.4) \mu S(2017: 46.1( \pm 23) \mu S ; 2018$ : $43.3( \pm 19.58) \mu S)$, an average conductivity of surface water of $110.0( \pm 41.1) \mu \mathrm{S}(2017$ : $58.1( \pm 19.1) \mu \mathrm{S}$; 2018: $38.2( \pm 26.7) \mu \mathrm{S})$, and the average for spring water was $105.4( \pm 38.5) \mu \mathrm{S}$ (2017: $39.7( \pm 22.9) \mu S ; 2018: 39.2( \pm 14.9) \mu S)$.

\subsection{E. coli and Coliform Bacteria}

All 24 drinking water samples were analyzed for Escherichia coli (E. coli) and Total Coliform bacteria, see Figure 3 and Figure 4, respectively. E. coli CFU (colony forming units per $100 \mathrm{ml}$ sample) shows a weak positive correlation with altitude. The maximum number of E. coli CFU (144 CFU) were found in samples taken from a small tributary used for drinking water in the village of Toktok $(\sim 2890 \mathrm{~m})$. Only one village source, Debuche $(\sim 3740 \mathrm{~m})$, tested negative $(0$ $\mathrm{CFU})$ for $E$. coli all three years.

Samples collected in 2016, in general, had the lowest levels of $E$. coli with a range between 0 and $60 \mathrm{CFU}$ and an average of $7.7( \pm 14.3) \mathrm{CFU}$ for all drinking water samples. Surface water samples $(16.4( \pm 22.7) \mathrm{CFU})$ contain more $E$. coli than spring water $(3.9( \pm 6.7) \mathrm{CFU})$. In 2017 and 2018 E. coli levels were higher. 2017 samples contained between 0 and $91 \mathrm{CFU}$ and an average of $17.0( \pm 24.4)$ CFU for all samples, with surface water averaging $18.4( \pm 22.0) \mathrm{CFU}$ and spring water averaging $16.3( \pm 26.0) \mathrm{CFU}$. In $2018 \mathrm{E}$. coli values ranged between 0 and $144 \mathrm{CFU}$ and an average of $20.1( \pm 32.8) \mathrm{CFU}$ for all samples, with surface water averaging $33.1( \pm 52.5) \mathrm{CFU}$ and spring water averaging $12.6( \pm 15.9) \mathrm{CFU}$.

Results for CFU of Total Coliforms are similar to E. coli (Figure 4). Samples 
collected in 2016, in general, had the lowest levels of Total Coliforms with a range between 0 and $200 \mathrm{CFU}$ and an average of $65( \pm 72) \mathrm{CFU}$ for all drinking water samples. 2017 samples contained between 3 and $1125 \mathrm{CFU}$ with an average of $322( \pm 341) \mathrm{CFU}$, and in 2018 Total Coliform values ranged between 0 and $377 \mathrm{CFU}$ and an average of $80( \pm 103) \mathrm{CFU}$ for all samples.

\subsection{Precipitation Data for 2016, 2017 and 2018}

In order to fully understand the interplay between precipitation and water contamination it is important to look at precipitation as both rain and snow. It is also important to look at both the long-term and the short-term impact of precipitation
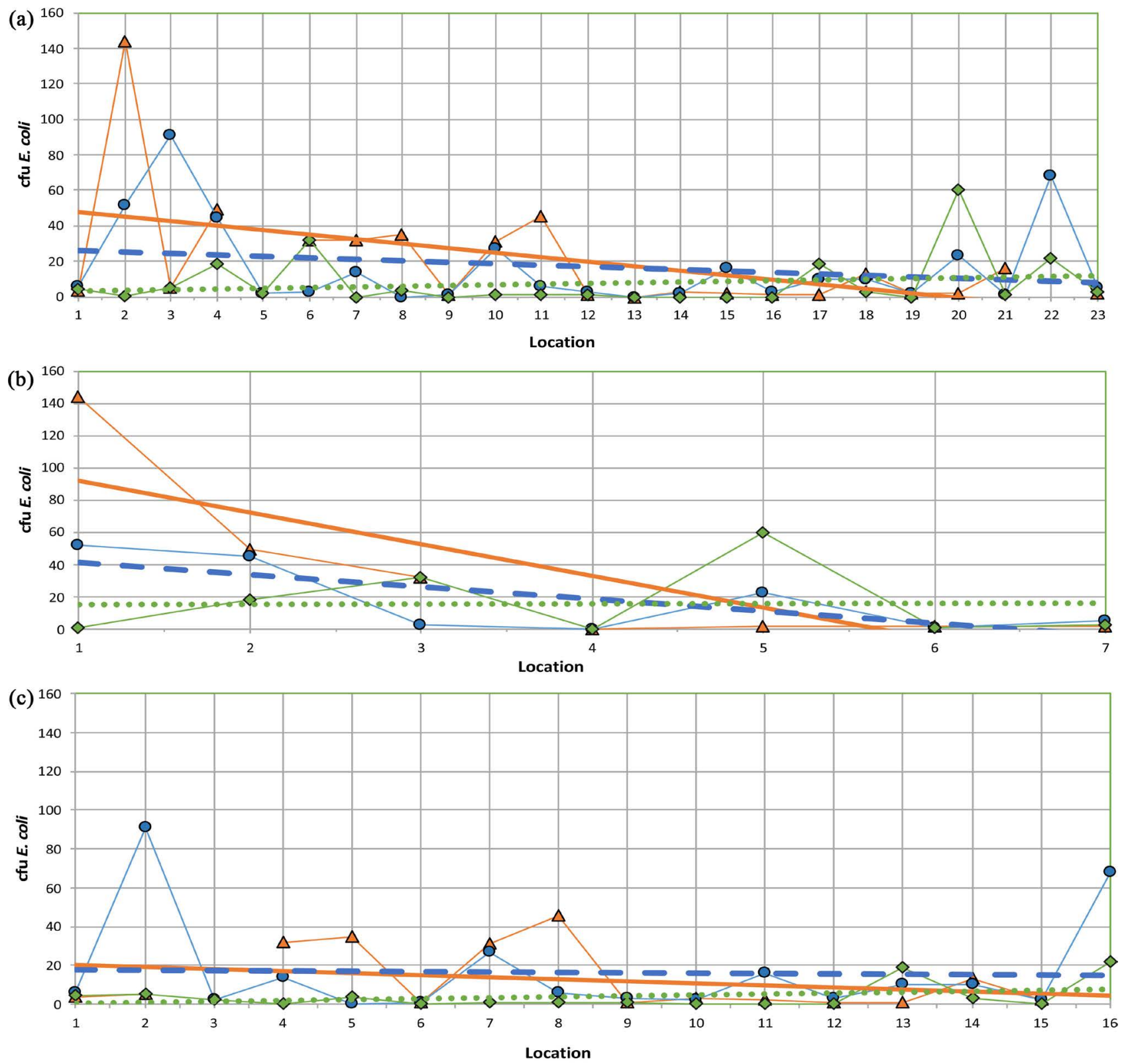

Figure 3. E. coli plotted against location (in order of increasing altitude); (a) all samples, (b) surface water and (c) spring samples. 2016: filled diamonds and dotted line, 2017: filled circles and dashed line, 2018: filled triangles and solid line. 

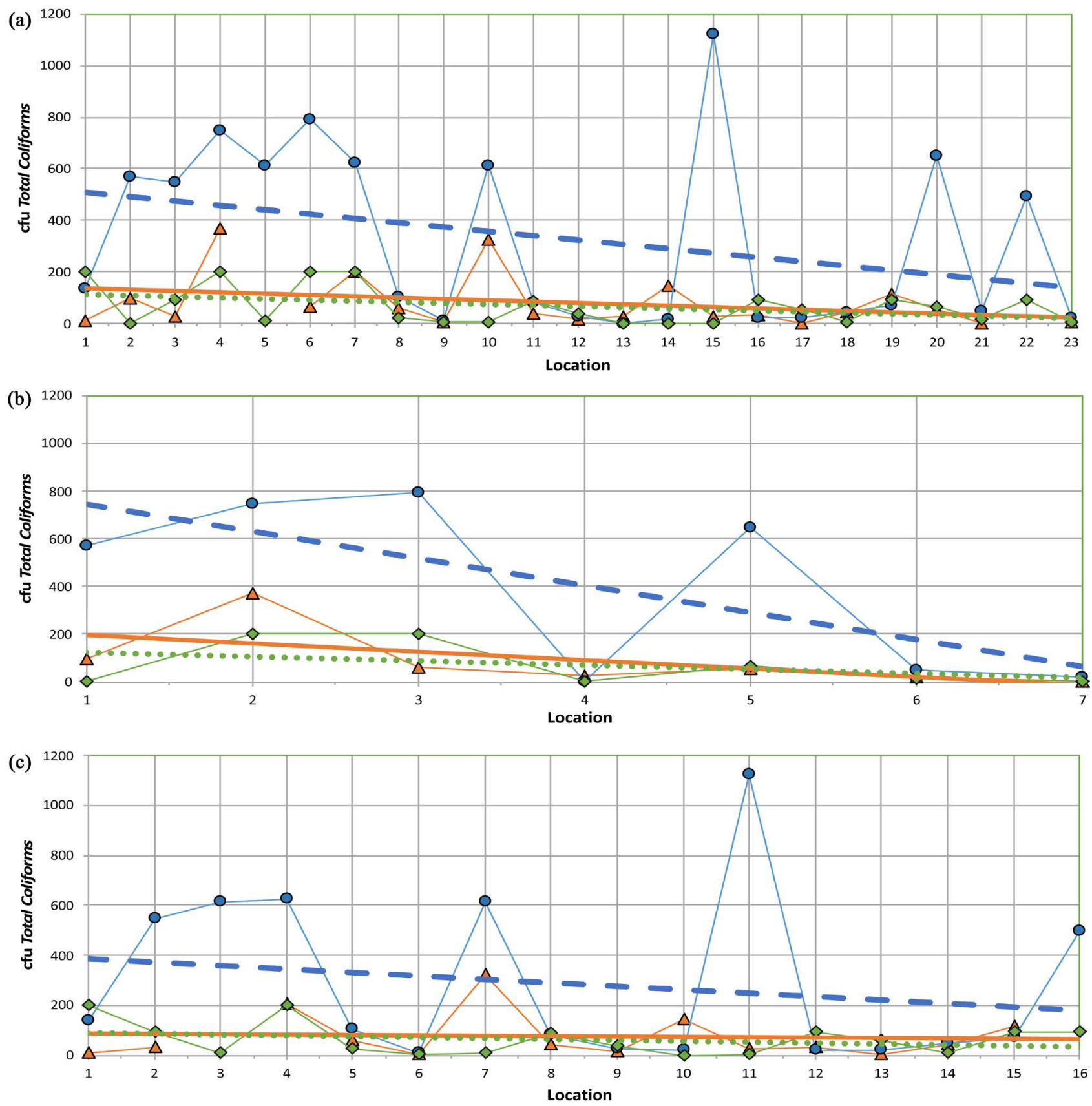

Figure 4. Total Coliforms plotted against location (in order of increasing altitude); (a) all samples, (b) surface water and (c) spring samples. 2016: filled diamonds and dotted line, 2017: filled circles and dashed line, 2018: filled triangles and solid line.

prior to sampling. Hence, as our sampling occurred in 2016, 2017 and 2018, precipitation data for 2015-2018 is included (Table 1). The data given here is sourced from the Government of Nepal, Ministry of Energy, Water Resources and Irrigation, Department of Hydrology and Meteorology [28] and comes from the meteorological station located in the village of Jiri; $1905 \mathrm{~m}$ asl, $27^{\circ} 38^{\prime} \mathrm{N}$ $86^{\circ} 14^{\prime} \mathrm{E}$ (Figure 1).

Average yearly precipitation (as total rainfall) in Jiri between 1960 and 1990 was $2353 \mathrm{~mm}$ [28]. In 2015 the average precipitation was $1869 \mathrm{~mm}$, in 2016 the 
Table 1. Precipitation data [28].

\begin{tabular}{cccc}
\hline & 2015 & 2016 & 2017 \\
\hline Total annual precipitation & $1869 \mathrm{~mm}$ & $2302 \mathrm{~mm}$ & $1660 \mathrm{~mm}$ \\
Peak monsoon precipitation (July) & $669 \mathrm{~mm}$ & $838 \mathrm{~mm}$ & $634 \mathrm{~mm}$ \\
\hline Total precipitation for 1 month prior to sampling & $30 \mathrm{~mm}$ & $58 \mathrm{~mm}$ & $199 \mathrm{~mm}$ \\
Total precipitation for 3 months prior to sampling & $64 \mathrm{~mm}$ & $73 \mathrm{~mm}$ & $247 \mathrm{~mm}$ \\
\hline
\end{tabular}

Note: 2018 total annual precipitation and peak monsoon data is not included as it post-dates all sampling and is therefore not relevant.

average precipitation was $2302 \mathrm{~mm}$ and in 2017 the average precipitation was $1660 \mathrm{~mm}$. As such, rainfall in 2016 approached normal (average) values for the region, whereas 2015 and 2017 both experienced less rainfall. The same trend is found in peak monsoon rain whereby 2015 and 2017 experienced $669 \mathrm{~mm}$ and $634 \mathrm{~mm}$, respectively, but peak rainfall in July 2016 was over $838 \mathrm{~mm}$. Similarly, snowfall in 2016 was $>200 \mathrm{~cm}$ higher than in 2015 and 2017. In summary, yearly precipitation for 2016 was significantly higher than for 2015 and 2017 [28].

Short term precipitation, directly prior to sampling, showed a different trend. Looking at data for three months prior to sampling means that for 2016 and 2017 the data includes January, February and March, and for 2018 the data includes February, March and April. In 2016, the total precipitation (as rainfall) prior to sampling was $64 \mathrm{~mm}$. In 2017 the total precipitation (as rainfall) prior to sampling was $73 \mathrm{~mm}$, and in 2018 the three months prior to sampling experienced a total rainfall of $247 \mathrm{~mm}$. The data for the month prior to sampling shows the same trend whereby 2018 experienced the most rainfall, $199 \mathrm{~mm}$, whereas 2017 and 2016 were progressively dryer with $58 \mathrm{~mm}$ and $30 \mathrm{~mm}$ respectively. In respect to short term precipitation prior to sampling, 2016 was the driest of the three years sampled and 2018 was the wettest.

Looking at precipitation trends in the High Himalayas, it has been noted by several authors [29] [30] that although extreme rainfall events have been increasing over the past 50 years, precipitation during the winter, pre-monsoon and post-monsoon seasons has been decreasing. GON [30] shows that with respect to data collected between 1960 and 1990, extreme precipitation events in the region have increased during the monsoon season, but decreased throughout the remainder of the year. This is particularly evident in 2016 whereby the pre-monsoon rains were very low, but peak monsoon rain and the overall yearly precipitation were high. In addition, overall precipitation has increased at a rate of $6.6 \mathrm{~mm} / \mathrm{yr}$ since 1971, while simultaneously maximum daily temperatures have also increased by $0.52^{\circ} \mathrm{C}$ per year. Current precipitation trends in the region show that more rain now falls during the monsoon season, and less precipitation (and therefore less snow) during the remainder of the year. The result is more flooding and less glacial growth [29] [31]. 


\section{Discussion}

The quantitative assessment of drinking water in the SNPBZ is relatively new. The only previous work, by Sharma et al. [32] and Ghimire et al. [6] [7], focused entirely on the major rivers and lakes within the park which are not commonly used as sources for drinking water. The first studies of $E$. coli and coliform bacteria in drinking water conducted by Nicholson et al. [9] [10] [11]. These studies have shown that much of the drinking water, and all of the rivers, contained $E$. coli and coliform bacteria, especially at lower altitudes. Ghimire et al. [6] suggested a link between unmanaged and/or poorly managed solid waste disposal, open defecation, and water contamination, which was supported by Nicholson et al. [9] [10] [11]. This study is the first longitudinal study of drinking water quality in the SNPBZ and the results suggest a strong relationship between precipitation and drinking water contamination, which lends further support to the conclusions of Ghimire et al. [6].

\subsection{Nepali and WHO Drinking Water Quality Standards}

Nepali National Drinking Water Quality Standards allow no fecal coliforms ( $E$. coli) in drinking water. Only one drinking water source, in the village for Debuche, met the Nepali National Drinking Water Quality standards of 0 CFU $E$. coli in all three years. WHO [33] provides a scale whereby 0 CFU E. coli is deemed compliant, $1-10 \mathrm{CFU}$ is considered low risk, $10-100 \mathrm{CFU}$ is considered moderate risk, and above $100 \mathrm{CFU}$ is considered high risk. The majority of samples, across all years, falls into the low-moderate risk categories [33]. 2016 samples show the least amount of fecal contamination with 7 samples containing $0 \mathrm{CFU}$ and 8 samples containing fewer than $10 \mathrm{CFU}$. In fact, in 2016 all but 2 spring samples fell into the WHO low risk or compliant categories. Both 2017 and 2018 samples contained more fecal contamination, with only 2 samples in 2017 and 1 sample in 2018 containing 0 CFU of E. coli. However, again the majority of the samples are low to moderate risk. Only one sample, Toktok, contained more than 100 colonies and was classified as high risk [33].

There is a weak negative correlation between E. coli and altitude in both surface and spring water samples. This is interpreted to be related to both decreasing temperature with altitude and decreasing population with altitude. Lower altitude regions are warmer, have a higher population and significantly more tourists. Hence at higher altitudes, water samples are less affected by fecal contamination. These higher-altitude samples are more likely to be in low or no risk [33] and meet Nepali National Drinking Water Quality Standards. However, it should be noted that this does not apply to stored water as is typically found in households and teahouses.

All of the samples tested met drinking water standards (both Nepali and WHO) for physical parameters. Temperature directly correlates with altitude, hence scatter in the data is likely to be the result of surface temperature fluctuations and/or the amount of surface water in the sample tested. All of three years 
of spring sample temperatures decrease with altitude, with similar trend lines, and there is little difference between their average high and low temperatures. However, 2017 samples have the lowest temperatures at the highest altitudes which support the hypothesis that 2017 samples have the highest surface water contribution.

Nicholson et al. [9] tentatively interpreted the relationship between increasing $\mathrm{pH}$ with increasing altitude as being the result of the geology and water-rock interactions; however, this study presents evidence contrary to this conclusion. There are two things to consider here: firstly, all three years show an increase in $\mathrm{pH}$ with altitude and, secondly, 2016 consistently has the lowest $\mathrm{pH}$. Given that the highest altitude rocks in the sample area are limestone, which produces higher $\mathrm{pH}$ water than the metamorphic units more commonly found through the field area, it is possible that contact with the limestone rock unit has resulted in the increase in $\mathrm{pH}$. However, the $\mathrm{pH}$ of samples from 2016 is consistently lower than those from 2017 and 2018. The 2016 samples also have higher conductivity which indicates an increased water-rock reaction. If the limestone was responsible for the increasing $\mathrm{pH}$ then the 2016 samples should have the highest $\mathrm{pH}$ of all three years. Recent work by Sundriyal et al. [34] measured the $\mathrm{pH}$ of snow on the central Himalayan Dokriani Glacier. They found that the $\mathrm{pH}$ of pre-monsoon glacial snow ranged between 5.10 and 7.09 (with a mean of 6.25) in 2013. They returned and resampled the same locations in 2015 and found that the pre-monsoon glacial snow had a $\mathrm{pH}$ range between 6.32 and 8.07 with a mean of 7.01. Sundriyal et al. [34] do not directly discuss the implications of their $\mathrm{pH}$ data but they do conclude that the main source of deposition of cations on the glacier are valley dust and sea salt aerosol while the source of the major anions is mainly human activities and scavenging action of the atmosphere. The high $\mathrm{pH}$ of glacial snow in the Himalayan Mountains is relevant to this study as this information (combined with the fact that the surface water in the region has a higher $\mathrm{pH}$ than the corresponding spring water, at the same elevations) suggests that the $\mathrm{pH}$ of the precipitation is dominating the $\mathrm{pH}$ of the drinking water. This supports the interpretation that the 2016 spring samples have less surface contamination; and suggests that longer residence time in the aquifer, and long interaction with the predominately lower $\mathrm{pH}$ metamorphic units, has resulted in a decrease in $\mathrm{pH}$.

\subsection{Link between Precipitation and Bacterial Contamination}

The short-term and annual precipitation data is important to the results of this study as they help elucidate community vulnerability to climate change, and emphasize the long-term risks to the $>1.4$ billion people living downstream of the High Himalaya Mountains.

Figure 3 clearly shows that 2016 has the lowest bacterial contamination (both

E. coli and Total Coliforms) and also the lowest $\mathrm{pH}$ and the highest conductivity of the three years sampled. Overall Total Coliform contamination is the highest 
in 2017 and $E$. coli contamination is highest in 2018; however, for spring water 2017 has the highest contamination of both $E$. coli and Total Coliforms. In terms of physical parameters (Figure 2), both 2017 and 2018 are very similar with regards to $\mathrm{pH}$ and conductivity, and have higher $\mathrm{pH}$ and lower conductivity than 2016. 2018 shows a very flat elevation profiles for surface water physical parameters, particularly temperature and conductivity, whereas 2017 data shows a steep negative correlation between temperature and altitude. In contrast, data from springs in 2018 and 2017 are remarkably similar.

Based on the precipitation data (Table 1), whereby both the entire year of 2015 and the three months preceding the 2016 sampling (only $30 \mathrm{~mm}$ precipitation) were very dry, we suggest that the shallow springs and the surface water used for drinking water in 2016 have a higher percentage of melt water and less surface water than the two succeeding years, resulting lower levels of bacterial contamination in 2016. This also ties in with the physical parameters whereby 2016 samples have the highest conductivity and the lowest $\mathrm{pH}$ suggesting a longer residence time in the aquifer.

The 2017 samples clearly have the highest overall bacterial contamination. The 2016 monsoon rain was heavy, the total precipitation during 2016 was very high, and the three months preceding the sampling had a precipitation of 73 $\mathrm{mm}$; this suggests that 2017 water samples include a higher percentage of precipitation/surface water than the 2016 samples.

The divergence in data from 2017 to 2018 is indicative of the different impacts of annual versus short-term precipitation. Figure 3 and Figure 4 best illustrate this difference, as the data from 2017 has the highest Total Coliform contamination in surface water?, whereas 2018 has the highest E. coli contamination in surface water, whereas both years have similar levels of $E$. coli in springs. Annual precipitation for 2016 approached normal levels and was significantly higher than 2017 precipitation (total precipitation of $2302 \mathrm{~mm}$ and $1660 \mathrm{~mm}$ respectively). However, the month directly preceding 2018 sampling had $199 \mathrm{~mm}$ of precipitation, which is almost 4 times more than in $2017(58 \mathrm{~mm})$ and 6 times more than in $2016(30 \mathrm{~mm})$. As such, the elevated levels of E. coli in the 2018 surface water reflect the higher levels of surface run-off. The levels of $E$. coli in the spring water data for 2018 and 2017 show a diverging patter where the contamination is similar at lower altitudes but at higher altitudes the 2018 water has less fecal contamination.

Combining the precipitation data, physical parameters, and bacterial contamination shows that there are two major factors which impact drinking water quality in the SNPBZ: annual precipitation and extreme precipitation. The higher the levels of monsoon precipitation the more fecal contamination is found the following year in the drinking water. Similarly, after a short-term extreme precipitation event fecal contamination is higher. Given that the number of extreme precipitation events during the monsoon season-and in general, overall monsoon precipitation-is rising, this poses a threat to communities 
during the monsoon and post-monsoon season due to both flooding [35] and associated water contamination. However, as the climatic trends suggest a decrease in non-monsoon precipitation [36] [37], the drinking water quality throughout the remainder of the year should be safer. Unfortunately, the decrease in non-monsoon precipitation is contributing to an overall decrease in glacial discharge [38] [39]. The 2016 data suggests that during periods of little precipitation, drinking water has a higher percentage of meltwater, and a decrease in Himalayan glaciers is likely to heighten dry-season water scarcity, i.e. drought conditions and crop failure as outlined by Gain et al. [40]. Again, this will impact not only the people of the SNPBZ and the Higher Himalayan region, but also the millions of people dependent on the Himalayan Mountains for their water resources.

\subsection{Implications for the Future}

Few studies have focused on seasonal precipitation patterns, catchment storage dynamics, and groundwater recharge in mountainous regions within the framework of global warming [41]. Dettinger and Earman [42] state that the challenges of understanding climate-change effects on groundwater are unprecedented as neither the direct nor the indirect effects on hydrological processes and groundwater resources have been sufficiently explored. Hence the SNPBZ's reliance on shallow groundwater (in the form of shallow springs) puts these communities in a particularly vulnerable and difficult to predict situation.

Water contamination and availability in the SNPBZ are complicated by several facets including economics, governance, environmental degradation, and climate change. Locally, there is much debate about how to develop a sustainable economy without exacerbating environmental and cultural degradation. Since 2005, the Park Management Plan [43] [44] has emphasized community self-governance, including local stewardship of natural resources [12] and in 2018, new local governance committees and leaders within the Sherpa community are making safe drinking water a priority. Providing stakeholders with water quality data generated from studies such as this will serve to strengthen their ability to address these issues as a community and build resilience for the future.

The issue of climate change is of particular concern to the future of the region, especially the impact water on resources, and hence how water resources are managed is incredibly important. Like many mountain systems around the world, the Himalaya Mountains form the headwaters for several major river systems and provide critical water resources to people downstream [45] through the mechanisms of water retention and storage dominated by snowmelt runoff [46] [47] [48]. Currently, climate change has resulted in glacial melting and recession [49] [50] [18], and resulted in changes to regional climate patterns which impact surface and ground water [29]. The resulting changes are predicted to cause a reduction in dry-season water discharge, an increase in peak discharge 
[51], and a general decrease in water resources [52]. Despite these threats, there are few detailed studies of the current and future impacts of global warming on Himalayan Mountain water resources.

The results of this study clearly show that the communities of the high Himalayan region, specifically the SNPBZ, are vulnerable to increased water contamination during period of high and/or extreme precipitation. These same communities are likely encounter increased water scarcity during the winter, preand post-monsoon seasons. It is likely that mountain communities around the globe are facing similar situations. By using quantitative water quality data to better understand how local water resources respond to climate change, government agencies will have better tools to manage these water resources, both in the high mountain regions and in downstream regions.

\section{Conclusions}

1) Only one drinking water source, in the village of Debuche, met the Nepali National Drinking Water Quality standards of 0 CFU E. coli across all three years. The majority of samples, across all years, fall into the low-moderate risk categories [33] and fail Nepali National Drinking Water Standards.

2) 2016 samples show the least amount of fecal contamination; with all but 2 spring samples in the WHO low risk or compliant categories. Both 2017 and 2018 samples contained more fecal contamination, with the majority of the samples are low to moderate risk [33].

3) Drinking water sourced from springs generally contains less fecal contamination than drinking water sourced from surface water.

4) The overall trend for all samples, in all years, are decreasing temperature and conductivity, and increasing $\mathrm{pH}$ with altitude.

5) Combining the precipitation data, physical parameters and bacterial contamination, it shows that there are two major factors which impact drinking water quality in the SNPBZ: annual precipitation and extreme precipitation. The higher the levels of monsoon precipitation are, the more fecal contamination is found the following year in the drinking water. Similarly, after a short-term extreme precipitation event, fecal contamination is higher. Fecal contamination of springs is lower after periods of low precipitation.

6) The data suggests that during a period of little precipitation, drinking water has a higher percentage of meltwater.

The long-term and downstream implications of our data suggest that drinking water resources in the region are vulnerable to climate change, particularly changes in precipitation and glacial melting. Decreasing Himalayan glaciers are likely to heighten dry-season water scarcity, while increased monsoon and extreme precipitation events increase water contamination (and flooding). This will impact not only the people of the SNPBZ and the Higher Himalayan region, but also the $\sim 1.4$ billion people dependent on the Himalayan Mountains for their water resources. 


\section{Geolocation Information}

This study is located within the Sagarmatha National Park and Sagarmatha National Park Buffer Zone, Nepal (27 $\left.56^{\prime} \mathrm{N} 86^{\circ} 44^{\prime} \mathrm{E}\right)$.

\section{Acknowledgements}

The authors are grateful to the following people and organizations for their support: Micrology Labs ${ }^{\circledR}$, Ang Norbu Sherpa (Holiday Namche Hotel), Ang Pema Sherpa (Valley View Khumjung Hotel), the Sagarmatha National Park Service and everyone that helped with sampling. This study was financially supported by Ball State University.

\section{Conflicts of Interest}

The authors declare no conflicts of interest regarding the publication of this paper.

\section{References}

[1] World Health Organization (2013) World Health Statistics 2013. World Health Organization, Geneva.

[2] World Health Organization (2017) Guidelines for Drinking-Water Quality, 4th Edition, Incorporating the 1st Addendum, WHO, Geneva, Switzerland.

[3] Ghimirie, N.P. (2012) Nepal Tourism Statistics, Government of Nepal: Ministry of Culture, Tourism and Civil Aviation Planning and Evaluation Division, Statistical Section Singha Durbar, Kathmandu.

[4] Salerno, F., Viviano, G., Manfredi, E.C., Caroli, P., Thakuri, S. and Tartari, G. (2013) Multiple Carrying Capacities from a Management-Oriented Perspective to Operationalize Sustainable Tourism in Protected Areas. Journal of Environmental Management, 128, 116-125. https://doi.org/10.1016/j.jenvman.2013.04.043

[5] Byers, A. (2005) Contemporary Human Impacts on Alpine Ecosystems in the Sagarmatha (Mt Everest) National Park, Khumbu, Nepal. Annals of the Association of American Geographers, 95, 112-140. https://doi.org/10.1111/j.1467-8306.2005.00452.x

[6] Ghimire, N.P., Jha, P.K. and Caravello, G. (2013) Physico-Chemical Parameters of High-Altitude Rivers in the Sagarmatha (Everest) National Park. Nepal. Journal of Water Resource and Protection, 5, 761-767. https://doi.org/10.4236/jwarp.2013.58077

[7] Ghimire, N.P., Jha, P.K. and Caravello, G. (2013) Water Quality of High-Altitude Lakes in the Sagarmatha (Everest) National Park, Nepal. Journal of Environmental Protection, 4, 22-28. https://doi.org/10.4236/jep.2013.47A003

[8] Caravello, G.U., Boselli, A.M., Bertollo, P. and Baroni, A. (2007) Assessing Ecosystem Health: An Analysis of Tourism Related Change and Impact in Khumbu Valley. International Journal of Ecology, 14, 45-64. https://doi.org/10.3126/eco.v14i0.4826

[9] Nicholson, K.N., Hayes, E., Neumann, K., Dowling, C. and Sharma, S. (2016) Drinking Water Quality in the Sagarmatha National Park (Mt. Everest) Nepal. Journal of Geoscience and Environment Protection, 4, 43-53. https://doi.org/10.4236/gep.2016.44007 
[10] Nicholson, K.N., Neumann, K., Dowling, C. and Sharma, S. (2017) Faecal Coliforms as Indicators for Improved Handling of Drinking Water in the Sagarmatha National Park, Nepal. Journal of Environmental Management and Sustainable Development, 6, 411-428. https://doi.org/10.5296/emsd.v6i2.11982

[11] Nicholson, K.N., Neumann, K., Dowling, C., Gruver, J., Sherman, H. and Sharma, S. (2018) An Assessment of Drinking Water Sources in Sagarmatha National Park (Mt Everest Region), Nepal. Mountain Research and Development, 38, 353-364. https://doi.org/10.1659/MRD-JOURNAL-D-17-00024.1

[12] Daconto, G. and Sherpa, L.N. (2010) Applying Scenario Planning to Park and Tourism Management in Sagarmatha National Park, Khumbu, Nepal. Mountain Research and Development, 30, 103-112. https://doi.org/10.1659/MRD-JOURNAL-D-09-00047.1

[13] Garrad, R., Kohler, T., Wiesmann, U., Price, M.F., Byers, A.C. and Sherpa, A.R. (2012) Depicting Community Perspectives: Repeat Photography and Participatory Research as Tools for Assessing Environmental Services in Sagarmatha National Park, Nepal. Journal on Protected Mountain Areas Research and Management, 4, 9-19. https://doi.org/10.1553/eco.mont-4-2s21

[14] Mukherji, A., Molden, D., Nepal, S., Rasul, G. and Wagnon, P. (2015) Himalayan Waters at the Crossroads: Issues and Challenges. International Journal of Water Resources Development, 31, 151-160. https://doi.org/10.1080/07900627.2015.1040871

[15] Pradhan, N.S., Sijapati, S. and Bajracharya, S.R. (2015) Farmers' Responses to Climate Change Impact on Water Availability: Insights from the Indrawati Basin in Nepal. International Journal of Water Resources Development, 31, 269-283. https://doi.org/10.1080/07900627.2015.1033514

[16] Gray, G.J., Enzer, M.J. and Kusel, J. (2001) Understanding Community-Based Forest Ecosystem Management. Journal of Sustainable Forestry, 12, 1-23. https://doi.org/10.1300/J091v12n03_01

[17] Manfredi, E.C., Flury, B., Viviano, G., Thakuri, S., Khanal, S.N., Jha, P.K., et al. (2010) Solid Waste and Water Quality Management Models for Sagarmatha National Park and Buffer Zone, Nepal. Mountain Research and Development, 30, 127-142. https://doi.org/10.1659/MRD-JOURNAL-D-10-00028.1

[18] Alford, D. and Armstrong, R. (2010) The Role of Glaciers in Stream Flow from the Nepal Himalaya. The Cryosphere Discussions, 4, 469-494. https://doi.org/10.5194/tcd-4-469-2010

[19] Okpokwasili, G.C. and Akujobi, T.C. (1996) Bacteriological Indicators of Tropical Water Quality. Environmental Toxicology. Water Quality International Journal, 11, 77-81. https://doi.org/10.1002/(SICI)1098-2256(1996)11:2<77::AID-TOX1>3.3.CO;2-P

[20] Hodegkiss, I.J. (1988) Bacteriological Monitoring of Hong Kong Marine Water Quality. Environment International, 14, 495-499. https://doi.org/10.1016/0160-4120(88)90410-2

[21] Cairneross, S., Carruthers, I., Curtis, D., Feachem, R., Bradley, D. and Baldwin, G. (1980) Evaluation for Village Water Supply Planning. Wiley, Chichester, UK.

[22] World Health Organization (1983) Guidelines for Drinking Water Quality. Third Edition, World Health Organization, Geneva.

[23] Harwood, V.J., Brownell, M., Perusek, W. and Whitelock, J.E. (2001) Vancomycin-Resistant Enterococcus sp. Isolated from Waste Water and Chicken Feces in the United States. Applied Environmental Microbiology, 67, 4930-4933. 
https://doi.org/10.1128/AEM.67.10.4930-4933.2001

[24] Pathak, S. and Gopal, K. (2001) Rapid Detection of Escherichia coli as an Indicator of Faecal Pollution in Water. Indian Journal of Microbiology, 41, 139-151.

[25] Vaidya, S.Y., Vala, A.K. and Dube, H.C. (2001) Bacterial Indicators of Faecal Pollution and Bhavnagar Coast. India Journal of Microbiology, 41, 37-39.

[26] Kistemann, T., Claben, T., Koch, C., Dangendorf, F., Fischeder, R., Gebel, J., Vacata, V. and Exner, M. (2002) Microbial Load of Drinking Water Reservoir Tributaries during Extreme Rainfall and Runoff. Applied Environmental Microbiology, 68, 2188-2197. https://doi.org/10.1128/AEM.68.5.2188-2197.2002

[27] Gruver, J., Nicholson, K.N., Neumann, K., Sharma, S. and Dowling, C. (2017) Water Quality in the Sagarmatha National Park, Nepal: A Modification of Viable Field-Based Testing Methods. Journal of Environmental Management and Sustainable Development, 6, 361-372. https://doi.org/10.5296/emsd.v6i2.10635

[28] Department of Hydrology and Meteorology, Government of Nepal, Ministry of Energy, Water Resources and Irrigation. http://www.dhm.gov.np/climate/

[29] Green, T.R., Taniguchi, M., Kooi, H., Gurdak, J.J., Allen, D.M., Hiscock, K.M., Treidel, H. and Aureli, A. (2011) Beneath the Surface of Global Change: Impacts of Climate Change on Groundwater. Journal of Hydrology, 405, 532-560. https://doi.org/10.1016/j.jhydrol.2011.05.002

[30] Government of Nepal (2011) 2011 Census Data, National Planning Commission Secretariat Central. Bureau of Statistics, Ramshah Path, Kathmandu, Nepal.

[31] Karki, R., Hasson, S., Schickhoff, U., Scholten, T. and Böhner, J. (2017) Rising Precipitation Extremes across Nepal. Climate, 5, 4.

https://doi.org/10.3390/cli5010004

[32] Sharma, C.M., Sharma, S., Gurung, S., Jutther, I., Bajracharya, R.M. and Pradhan, N.S. (2010) Ecological Studies with the Gokyo Wetlands, Sagarmatha National Park, Nepal. In: Jha, P.K. and Khanal, I., Eds., Contemporary Research in Sagarmatha (Mt. Everest) Region, Nepal (An Anthology), Nepal Academy of Science and Technology, Kathmandu, 139-154.

[33] World Health Organization (2011) Guidelines for Drinking Water Quality: Fourth Edition. World Health Organization, Geneva.

[34] Sundriyal, S., Shukla, T., Tripathee, L., et al. (2018) Deposition of Atmospheric Pollutant and Their Chemical Characterization in Snow Pit Profile at Dokriani Glacier, Central Himalaya. Journal of Mountain Science, 15, 2236-2246. https://doi.org/10.1007/s11629-017-4817-x

[35] Ragettli, S., Immerzeel, W.W. and Pellicciotti, F. (2016) Contrasting Climate Change Impact on River Flows from High-Altitude Catchments in the Himalayan and Andes Mountains. Proceedings of the National Academy of Sciences of the United States of America, 113, 9222-9227. https://doi.org/10.1073/pnas.1606526113

[36] Nepal, S. and Shrestha, A.B. (2015) Impact of Climate Change on the Hydrological Regime of the Indus, Ganges and Brahmaputra River Basins: A Review of the Literature. International Journal of Water Resources Development, 31, 201-218. https://doi.org/10.1080/07900627.2015.1030494

[37] Shea, J.M., Wagnon, P., Immerzeel, W.W., Biron, R., Brun, F. and Pellicciotti, F. (2015) A Comparative High-Altitude Meteorological Analysis from Three Catchments in the Nepalese Himalaya. International Journal of Water Resources Development, 31, 174-200. https://doi.org/10.1080/07900627.2015.1020417

[38] Bolch, T., Kulkarni, A., Kääb, A., Huggel, C., Paul, F., Cogley, J.G., Frey, H., Kargel, J.S., Fujita, K., Scheel, M., et al. (2012) The State and Fate of Himalayan Glaciers. 
Science, 336, 310-314. https://doi.org/10.1126/science.1215828

[39] Immerzeel, W.W., Pellicciotti, F. and Bierkens, M.F.P. (2013) Rising River Flows throughout the Twenty-First Century in Two Himalayan Glacierized Watersheds. Nature Geoscience, 6, 742-745. https://doi.org/10.1038/ngeo1896

[40] Gain, A.K. and Wada, Y. (2014) Assessment of Future Water Scarcity at Different Spatial and Temporal Scales of the Brahmaputra River Basin. Water Resources Management, 28, 999-1012. https://doi.org/10.1007/s11269-014-0530-5

[41] Ajami, H., Troch, P.A., Maddock III, T., Meixner, T. and Eastoe, C. (2011) Quantifying Mountain Block Recharge by Means of Catchment-Scale Storage-Discharge Relationships. Water Resources Research, 47, W04504.

https://doi.org/10.1029/2010WR009598

[42] Dettinger, M.D. and Earman, S. (2007) Western Ground Water and Climate Change Pivotal to Supply Sustainability or Vulnerable in Its Own Right? Ground Water, 4, 4-5.

[43] Department of National Parks and Wildlife Conservation (2005) Sagarmatha National Park and Buffer Zone Management Plan. DNPWC, Kathmandu, Nepal.

[44] Department of National Parks and Wildlife Conservation (2006) Sagarmatha National Park Management and Tourism Plan 2006-2011. DNPWC, Kathmandu, Nepal.

[45] Ives, J.D. and Messerli, B. (1989) The Himalayan Dilemma: Reconciling Development and Conservation. John Wiley and Sons, London, UK.

[46] Serreze, M.C., Clark, M.P., Armstrong, R.L., McGinnis, D.A. and Pulwarty, R.S. (1999) Characteristics of the Western United States Snowpack from Snowpack Telemetry (SNOTEL) Data. Water Resources Research, 35, 2145-2160. https://doi.org/10.1029/1999WR900090

[47] Viviroli, D., Archer, D.R., Buytaert, W., Fowler, H.J., Greenwood, G.B., Hamlet, A.F., et al (2011) Climate Change and Mountain Water Resources: Overview and Recommendations for Research, Management and Policy. Hydrology and Earth System Science, 15, 471-504. https://doi.org/10.5194/hess-15-471-2011

[48] Schlaepfer, D.R., Lauenroth, W.K. and Bradford, J.B. (2012) Consequences of Declining Snow Accumulation for Water Balance of Mid-Latitude Dry Regions. Global Change Biology, 18, 1988-1997. https://doi.org/10.1111/j.1365-2486.2012.02642.x

[49] Kaser, G., Georges, C., Juen, I. and Mo lg, T. (2005) Low-Latitude Glaciers: Unique Global Climate Indicators and Essential Contributors to Regional Fresh Water Supply. A Conceptual Approach. In: Huber, U.M., Bugmann, H. and Reasoner, M.A., Eds., Global Change and Mountain Regions. An Overview of Current Knowledge, Springer, Dordrecht, 185-196. https://doi.org/10.1007/1-4020-3508-X_19

[50] Vuille, M., Francou, B., Wagnon, P., Juen, I., Kaser, G., Mark, B.G. and Bradley, R.S. (2008) Climate Change and Tropical Andean Glaciers: Past, Present and Future. Earth Science Reviews, 89, 79-96. https://doi.org/10.1016/j.earscirev.2008.04.002

[51] Barnett, T.P., Adam, J.C. and Lettenmaier, D.P. (2005) Potential Impacts of a Warming Climate on Water Availability in a Snow-Dominated Region. Nature, 438, 303-309. https://doi.org/10.1038/nature04141

[52] Intergovernmental Panel on Climate Change (2007) Climate Change 2007: The Physical Science Basis. In: Solomon, S., Qin, D., Manning, M., Chen, Z., Marquis, M., Avery, K.B., Tignor, M. and Miller, H.L., Eds., Contribution of Working Group I to the Fourth Assessment Report of the Intergovernmental Panel on Climate Change, Cambridge University Press, Cambridge and New York. 